\title{
A rare case: Retrocecal appendicitis adherent to the liver capsule
}

Hasan Börekçi' ${ }^{1}$ Sinan Karacabey², Mesut Sipahi', Zeynep Tuğba Özdemir ${ }^{3}$, Mustafa Fatih Erkoç

ABSTRACT The cases of appendicitis take an important place in the hospital emergency departments and it must be kept in mind in the differential diagnosis of patients presenting with abdominal pain. Related to cecum, the appendix can be found in many different positions; however, it is mostly observed descending intraperitoneally (31-74\%) and at the retrocecal region (26-65\%). In this case report, we present the case of a 26-year-old female patient admitted to the emergency room with a colic pain in the right upper quadrant for about 2 days. Computed tomography revealed contamination in the fatty plans around the cecum and adhesive retrocecal appendicitis from the liver to the retroperitoneum. Appendectomy was performed. The pathology result was gangrenous appendicitis. In the literature, there is no similar case of appendicitis with hepatic adhesions. In conclusion, we want to emphasize that physicians and surgeons in the emergency departments must be more careful during the differential diagnosis of a patient with appendicitis and atypical symptoms and a more detailed investigation is required.

Keywords: Appendicitis, retrocecal appendix, liver capsule

\section{INTRODUCTION}

Appendicitis cases play an important role in hospital emergencies and should be considered in the differential diagnosis of patients with abdominal pain (1). If the appendicitis cannot be diagnosed and the patients leave the hospital with another diagnosis, clinical complications such as appendix perforation or plastron state of intra-abdominal abscess can develop (2). The cecum appendix can be found in many different positions, particularly descending intraperitoneally (31-74\%) and at the retrocecal region (26-65\%). According to the location of the appendix, patients can be admitted with a different history and physical examination findings can also be different. One of them is an infection in the retrocecal appendix (3). Retrocecal appendicitis may present with different clinical symptoms. Due to the location of the retrocecal appendix, right lower quadrant tenderness may not be observed. Therefore, there could be difficulties in the diagnosis (4).

Cite this paper as: Börekci H, Karacabey S, Sipahi M, Özdemir ZT, Erkoç MF. A rare case: Retrocecal appendicitis adherent to the liver capsule. Turk J Surg 2017; 33: 227-229.

'Department of General Surgery, Bozok University School of Medicine, Yozgat, Turkey

2Department of Emergency, Bozok University School of Medicine, Yozgat, Turkey

${ }^{3}$ Department of Internal Medicine, Bozok University School of Medicine, Yozgat, Turkey ${ }^{4}$ Department of Radiology, Bozok University School of Medicine, Yozgat, Turkey

\section{Address for Correspondence} Hasan Börekci e-mail: hborekci@mynet.com

Received:31.10.2014

Accepted: 25.01.2015

Available Online Date: 14.07.2015

CC Copyright 2017

by Turkish Surgical Association

Available online at

www.turkjsurg.com
In half of the retrocecal appendicitis cases, atypical clinical symptoms can be observed (5). In this case, the appendix was in the retrocecal region and physical examination was obviously positive in the right upper quadrant. Right upper quadrant pain can rule out the diagnosis of appendicitis, and mostly suggests cholecystitis, gastritis, duodenal ulcer, and other liver or gallbladder pathologies; therefore, we wanted to present this unusual case in detail. In retrocecal appendicitis cases, the pararenal abscess can be observed added to the appendicitis or infection can also spread to the right paracolic space, right subphrenic, and subhepatic area $(6,7)$. If our case had a diagnosis other than appendicitis, in the following days, a retroperitoneal abscess could have occurred.

There is no similar case report to ours in the literature and we wanted to highlight that appendicitis cases can present with different clinical symptoms and during the differential diagnosis of patients presenting with abdominal pain, it should be kept in mind.

\section{CASE PRESENTATION}

A 26-year-old female patient admitted to the emergency room with a colic pain in the right upper quadrant for about 2 days. In her history, there were only two pregnancies and two live births.

Vital parameters were as follows; blood pressure (BP): $110 / 70 \mathrm{~mm}-\mathrm{Hg}$, pulse: $86 / \mathrm{min}$ fever: $37.8^{\circ} \mathrm{C}$.

In the physical examination; bowel sounds were normoactive with auscultation; there was tenderness in all abdominal regions and rebound in the right upper quadrant. No other findings were observed in the other systems. Acute cholecystitis was first diagnosed; blood tests and ultrasound (USG) were performed.

The results of the blood tests were as follows: WBC: $15800 / \mathrm{mm}^{3}, \mathrm{Hgb}: 13.6 \mathrm{~g} / \mathrm{dL}$, hematocrit: $39.8 \%$, urea $11 \mathrm{mg} / \mathrm{dL}$ Cr: $0.64 \mathrm{mg} / \mathrm{dL}$, AST: $12 \mathrm{IU} / \mathrm{L}, \mathrm{ALT}: 12 \mathrm{IU} / \mathrm{L}$, total bilirubin: $0.5 \mathrm{mg} / \mathrm{dL}$, direct bilirubin: $0.3 \mathrm{mg} / \mathrm{dL}$. 
USG showed normal gallbladder wall thickness and no calculi and no calculi or hydronephrosis in the kidneys.

Thus, the diagnosis of acute cholecystitis was excluded. In order to investigate the cause of pain in the abdomen, computed tomography (CT) was requested. CT revealed contamination in the fatty plans around the cecum and adhesive retrocecal appendicitis from the liver to the retroperitoneum. Contamination was also observed in the adipose tissue under the liver (Figure 1, 2).

After the general surgery consultation with the diagnosis of acute abdomen, the patient underwent surgery immediately. Appendectomy was performed with the right paramedian incision. The stump was buried and mesoplasty was performed. No other pathology was found in the abdomen. It was phlegmonous from the tip of the appendix and joined through retroperitoneum to the liver capsule (Figure 3 ). The pathology result revealed gangrenous appendicitis. Postoperatively, IV antibiotics and analgesics were started. She was mobilized the first day. She was discharged due to her well-being.

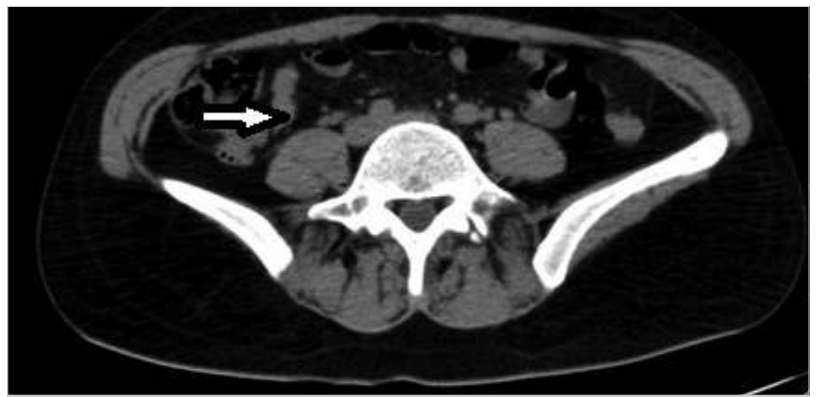

Figure 1. There is contamination in the fatty plans around the cecum

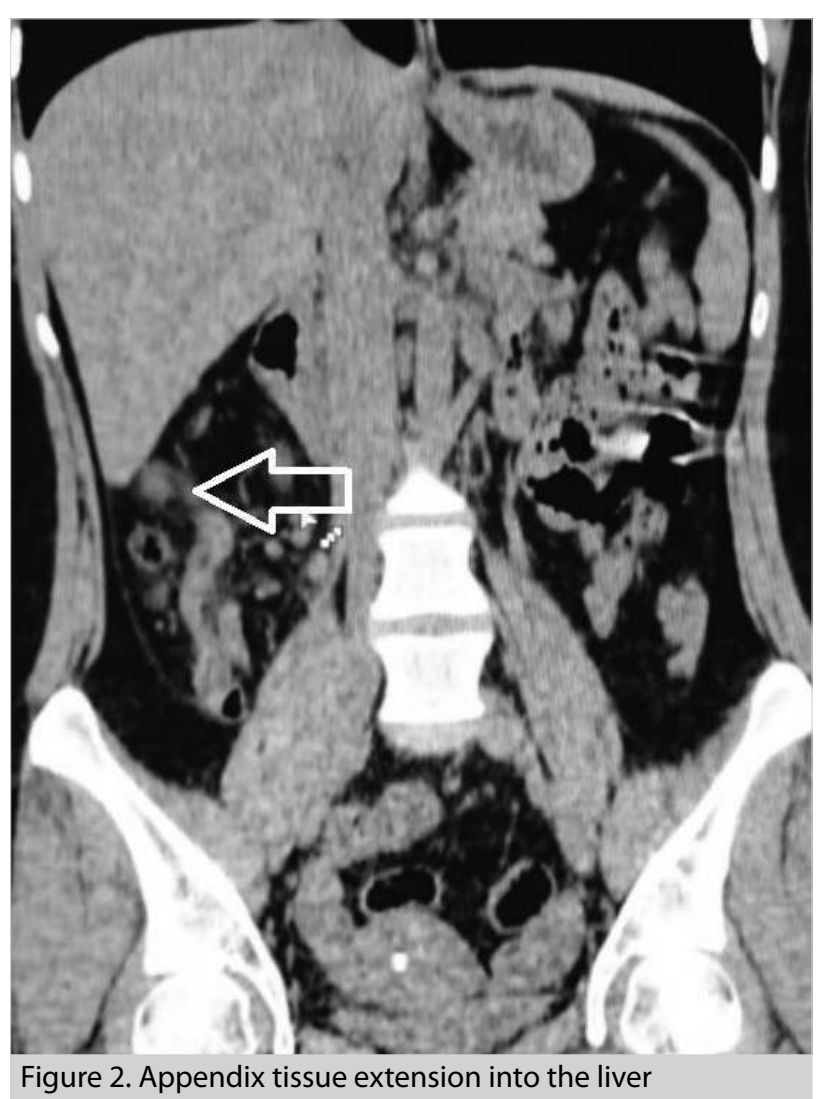

A signed written informed consent was taken from the patient.

\section{DISCUSSION}

Despite improvement in the techniques, the diagnosis of acute appendicitis remains challenging and the complications of the disease and the rate of negative laparotomy have not been reduced significantly (8). Complaints and symptoms may be atypical in patients with retrocecal appendicitis and can imitate right upper quadrant and right flank pathologies such as acute cholecystitis, renal colic, and diverticulitis (9). The location of the appendix can vary according to the position and shape of the cecum in organogenesis. The incidence of retrocecal appendix is $26-65 \%$ (10).

In this case, there was obviously tenderness, rebound, and defense in the right upper quadrant on physical examination. Moreover, she had anorexia and sometimes nausea complaints in the last 2 days. In appendicitis, generally pain starts from the epigastric area; anorexia symptoms and the right lower quadrant pain occur in the next few days. Therefore, this case is atypical. Routine USG is used in the diagnosis as the first step. A study on children's cases showed that the appendicitis diagnosis rate is $99 \%$ in suspected cases (11). Another study showed that the use of USG in the suspected cases diminished the negative laparotomies and the morbidity rate because of a delay in diagnosis (12).

However, in adults, it is indicated that non-contrast CT is superior to USG and CT decreases the false laparotomy rates (13). When clinically, gallbladder, hepatobiliary, or urinary tract pathologies are suspected in patients in the emergency departments, USG is frequently performed. With this in

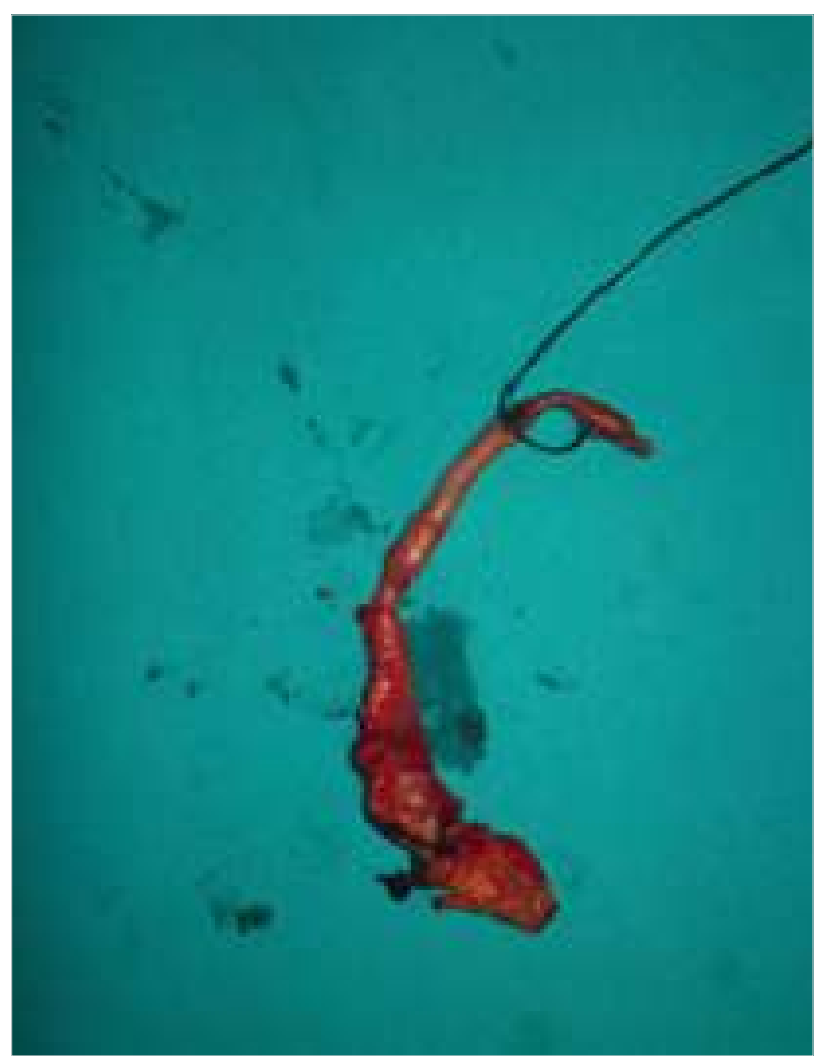

Figure 3. The phlegmonous end portion of the appendix tissue 
mind, liver abscess and fluid collection in the subhepatic or the right flank region can be observed on ultrasonography in retrocecal appendicitis cases (11). However, in this case, no pathology was detected on USG and the diagnosis was confirmed by $\mathrm{CT}$.

In the inflammatory process of retrocecal appendix, it can spread to the perirenal, adrenal, and subhepatic region (6). In our case, the appendix was attached to the liver tissue. In the literature, no cases of appendicitis with hepatic adhesions have been reported.

In this case, the cause of the right upper quadrant pain (presence of Murphy's sign) was the irritation of the liver fascia. Here we would like to emphasize again that further research should be performed by the physicians and surgeons in emergency rooms for the differential diagnosis of patients admitting with atypical symptoms. With wrong diagnosis and treatment, the patient's symptoms can become more complicated in the coming days and this can increase morbidity and mortality. We recommend that the use of additional imaging systems for the possible diagnoses without hesitation in patients with atypical signs is important. We first observed USG in our case and although we could not find any pathology, we required a non-contrast abdominal CT for the differential diagnosis. After $\mathrm{CT}$, we were able to properly diagnose.

\section{CONCLUSION}

When acute appendicitis is not suspected clinically in patients with abdominal pain in the emergency departments; we need to remember that the physical examination findings can differ according to the localization of the appendix. As observed in this case, one can be faced with retrocecal appendicitis attached to the liver capsule. Furthermore, it should be kept in mind that retrocecal appendicitis can be complicated and an abscess can occur in the abdomen.

Informed Consent: Written informed consent was obtained from patient who participated in this case.

Peer-review: Externally peer-reviewed.

Author Contributions: Concept - H.B.; Design - H.B., Z.T.Ö.; Supervision - M.S., S.K.; Funding - H.B., Z.T.Ö.; Materials - H.B.; Data Collection and/ or Processing - H.B., S.K., M.S., M.F.E.; Analysis and/or Interpretation - H.B., M.S., M.F.E.; Literature Review - H.B., Z.T.Ö.; Writer - H.B., Z.T.Ö.; Critical Review - M.S., M.F.E.; Other - S.K.

Conflict of Interest: No conflict of interest was declared by the authors.

Financial Disclosure: The authors declared that this study has received no financial support.

\section{REFERENCES}

1. Paulson EK, Kalady MF, Pappas TN. Clinical practice. Suspected appendicitis. N Engl J Med 2003; 348: 236-242. [CrossRef]

2. Bradley EL, $3^{\text {rd }}$, Isaacs J. Appendiceal abscess revisited. Arch Surg 1978; 113: 130-132. [CrossRef]

3. Wakeley CP. The position of the vermiform appendix as ascertained by an analysis of 10,000 cases. J Anat 1933; 67: 277-283.

4. Rasmussen OO, Hoffmann J. Assessment of the reliability of the symptoms and signs of acute appendicitis. J R Coll Surg Edinb 1991; 36: 372-377.

5. Lee SL, Ho HS. Acute appendicitis: is there a difference between children and adults? Am Surg 2006; 72: 409-413.

6. Meyers MA, Oliphant M. Ascending retrocecal appendicitis. Radiology 1974; 110: 295-299. [CrossRef]

7. Feldberg MA, Hendriks MJ, van Waes PF. Computed tomography in complicated acute appendicitis. Gastrointest Radiol 1985; 10: 289-295. [CrossRef]

8. Eryilmaz R, Alimoglu O, Bas G. Akut apandisitte tanı ve tedavide gecikme ve klinik sonuçları. Ulus Cerrahi Derg 2001; 17: 106-110.

9. Kim S, Lim HK, Lee JY, Lee J, Kim MJ, Lee AS. Ascending retrocecal appendicitis: clinical and computed tomographic findings. J Comput Assist Tomogr 2006; 30: 772-776. [CrossRef]

10. Rao PM, Rhea JT, Novelline RA, Mostafavi AA, Lawrason JN, McCabe CJ. Helical CT combined with contrast material administered only through the colon for imaging of suspected appendicitis. AJR Am J Roentgenol 1997; 169: 1275-1280. [CrossRef]

11. Lee JH, Jeong YK, Park KB, Park JK, Jeong AK, Hwang JC. Operatordependent techniques for graded compression sonography to detect the appendix and diagnose acute appendicitis. AJR Am J Roentgenol 2005; 184: 91-97. [CrossRef]

12. Eryilmaz R, Baş G, Alimoglu O, Ercan M, Sahin M. Akut apandisit şüpheli hastalarda ultrasonografinin ayırıcı tanıda artan önemi. Ulus Cerrahi Derg 2001; 17: 28-33.

13. Basak M, Çolakoğlu B, Ozkurt H, Yetkin G. Akut apandisitin kontrastsız spiral bilgisayarlı tomografi (BT) bulguları. Ulus Cerrahi Derg 2001; 17: 34-41. 